\title{
PERILAKU PENCAIRAN INFORMASI MAHASISWA JURUSAN PERPUSTAKAAN UNIVERSITAS ISLAM NEGERI SYARIF HIDAYATULLAH JAKARTA DALAM MASA PANDEMIK COVID
}

${ }^{1}$ Evi Zakiyah; ${ }^{2}$ Nailul Author; ${ }^{3}$ Rahmitha Prisilia; ${ }^{4}$ Alvin Adam Ramadhan; ${ }^{5}$ Nikita ${ }^{6}$ Meidina Zanuar; ${ }^{7}$ Muhammad Fathurrizki.

${ }^{7}$ Prodi Ilmu Perpustakaan dan Informasi UIN Syarif Hidayatullah Jakarta

*Korespondensi: evi.zakiyah@uinjkt.ac.id

\begin{abstract}
This research has been conducted to explain what has been changed from the search for information from students of the Faculty of Adab and Humanities at Syarif Hidayatullah State Islamic University Jakarta during Covid 19 Pandemic. The method used in this research is qualitative descriptive. This research used stratified sampling techniques that amounted to 83 informants from 500 college students of the Library Science Major at Syarif Hidayatullah State Islamic University Jakarta. The data collection techniques used in this research are literature studies and questionnaires. The results of this study were slightly constrained by the situation, which should amount to 83, only 31 people who filled out the questionnaire. To meet the needs of such information, the college students conducted a gradual information search consisting of: starting, to determine the topic before looking for information: chaining, to record the list of information needed; browsing, to looking for information in resources; differentiating, to sort through the information collected; monitoring, to follow the development of information; extracting, to looking for information at a specific source; verifying, checking data; and ending, end of information search.
\end{abstract}

Kata Kunci: information need, information seeking behavior, student majoring in library science

\begin{abstract}
ABSTRAK
Penelitian ini dilakukan untuk menjelaskan apa saja yang berubah dari pencarian informasi mahasiswa Fakultas Adab dan Humaniora Universitas Islam Negeri Syarif Hidayatullah Jakarta dalam masa Pandemik Covid 19. Metode yang digunakan dalam penelitian ini adalah kualitatif deskriptif. Penelitian ini menggunakan teknik stratified sampling yang berjumlah 83 informan dari 500 populasi Mahasiswa Jurusan Ilmu Perpustakaan Universitas Islam Negeri Syarif Hidayatullah Jakarta. Teknik pengumpulan data dalam penelitian ini ialah studi kepustakaan dan kuesioner. Hasil penelitian ini sedikit terkendala situasi dari seharusnya sejumah 83 hanya 31 orang saja yang mengisi kuesioner dikarnakan hanya 31 orang saja yang mengisi kuesioner. Dalam memenuhi kebutuhan informasi tersebut, mahasiswa melakukan pencarian informasi bertahap yang terdiri dari : starting, menentukan topic sebelum mencari informasi : chaining, mencatat daftar informasi yang dibutuhkan; browsing, mencari informasi di sumber-sumber informasi; differentiating, memilah-milah informasi yang dikumpulkan; monitoring, mengikuti perkembangan informasi; extracting, mencari informasi di sumber tertentu; verifying, pengecekan data; dan ending, akhir pencarian informasi.
\end{abstract}

Keyword :, perilaku pencarian informasi, pencarian dimasa pandemi 


\section{PENDAHULUAN}

Kebutuhan informasi dari seseorang tidak kenal waktu, kapan pun dan dimanapun mereka bisa saja dengan tiba-tiba membutuhkan informasi tidak hanya sekedar untuk mengerjakan tugas saja namun lebih dari itu. Hal ini menandakan perpustakaan harus siap sedia untuk memenuhi kebutuhan pemustakanya kapan pun dan dimanapun. Perpustakaan sebagai pusat dari berkumpulnya informasi-informasi dan juga ilmu-ilmu yang ada tentu merupakan hal yang sangat penting bagi manusia khususnya kaum akademisi bagaimanapun keadaannya, kapanpun waktunya perpustakaan tetap menjadi andalan mereka untuk mendapatkan pengetahuan yang mereka cari, perpustakaan dituntut untuk siap sedia kapanpun untuk memenuhi kebutuhan pemustakanya.

Perpustakaan pun perlu beradaptasi dengan apa yang terjadi dibumi ini, dalam 6 bulan banyak hal yang terjadi di Negara-negara dipenjuru bumi tidak terkecuali Indonesia yang membuat semua orang dan semua kegiatan perlu beradaptasi dengan sebaik mungkin dan secepat mungkin agar tetap bisa hidup dan survive dibumi ini dimulai dari sektor ekonomi, social budaya, pemerintahan, kesehatan dan termasuk pula sektor pendidikan.

Dimana pada sektor pendidikan institusi pendidikan harus dengan cepat dan tanggap menciptakan kebijakan-kebijakan yang berkaitan dengan pembelajaran terkhusus perpustakaan sebagai penyedia informasi dan ilmu pengetahuan bagi civitas akademika, dengan berubahnya pola kerja dengan ketentuan-ketentuannya maka akan berpengaruh pula dengan perilaku pencarian informasi dari pemustaka di perpustakaan. Perpustakaan harus sigap menanggapi perubahan perilaku pencarian informasi di perpustakaan ini karena jika perpustakaan tidak mampu beradaptasi dengan cepat akan berpengaruh kepada layanan yang ada diperpustakaan dan membuat perpustakaan tidak sinkron dengan pemustakanya.

Perpustakaan perlu mempelajari perubahan perilaku pencarian informasi dengan cepat dan menyediakan apa yang sekiranya diperlukan ditengah situasi seperti ini, penelitian ini sendiri bertujuan untuk menjelaskan apa saja yang berubah dari pencarian informasi mahasiswa Fakultas Adab dan Humaniora Humaniora Universitas Islam Negeri Syarif Hidayatullah Jakarta Dalam Masa Pandemik Covid 19. 


\section{TINJAUAN PUSTAKA}

\section{Perpustakaan Perguruan Tinggi}

\section{Pengertian Perpustakaan Perguruan Tinggi}

Perpustakaan perguruan tinggi adalah perpustakaan yang terdapat pada perguruan tinggi dengan tujuan utamanya yaitu membantu perguruan tinggi mencapai tujuannya yang berupa Tri Dharma Perguruan Tinggi yang meliputi pendidikan, penelitian dan pengabdian kepada masyarakat (Basuki,2010). Melihat dari pengertian diatas kita bisa melihat betapa pentingnya perpustakaan perguruan tinggi diadakan didalam sebuah institusi pendidikan karena terdapat peraturan pemerintah nomor 30 Tahun 1990 pasal 55 ayat 1 yang berbunyi setiap universitas / insitusi harus memiliki perpustakaan, pusat computer, laboratorium dan unsur penunjang lain yang diperlukan unruk penyelenggaraan perguruan tinggi.

Dalam rangka menunjang kegiatan Tri Darma Perguruan Tinggi, perpustakaan memiliki beberapa fungsi diantaranya ; fungsi edukasi, sumber informasi, penunjang riset, rekreasi, publikasi, deposit dan iterpretasi informasi. Berdasarkan pada Peraturan Pemerintah/PP No.5 tahun 1980 tentang pokok-pokok organisasi universitas atau institute, bahwa Perpustakaan Perguruan Tinggi termasuk kedalam Unit Pelayanan Teknis (UPT), yaitu sarana penunjang teknis yang merupakan perangkat kelengkapan universitas atau institute dibidang pendidikan dan pengajaran, penelitian dan pengabdian pada masyarakat.(Pawit,1991)

\section{Informasi}

Informasi diperoleh dari dua data dan observasi terhadap dunia serta meneruskannya melalui informasi (Basuki,2010). Sedangkan menurut Eastbrook dalam Yusuf dan Priyo mendefinisikan informasi "Suatu rekaman fenomena yang diamati, atau bisa juga berupa putusan-putusan yang dibuat (Pawit,1991)"

\section{Perilaku Pencarian Informasi}

\section{Perilaku Pencarian Informasi}

Information seeking behavior merupakan perilaku pencarian informasi yang bertujuan untuk mencari informasi yang dibutuhkan. Dalam pencarian informasinya, individu akan berinteraksi atau menggunakan sistem pencarian manual melalui media tekstual seperti buku, koran, majalah ilmiah dan perpustakaan, atau juga dapat menggunakan media yang berbasis computer seperti internet. Dengan kata lain perilaku pencarian informasi adalah suatu kegiatan atau aktivitas dari individu dalam mencari informasi yang dibutuhkan dengan suatu tujuan tertentu (Pawit,2010) 
Terdapat pula beberapa teori dari berbagai ahli tentang perilaku pencarian informasi. Ellis mengemukakan beberapa karakteristik perilaku pencariaan informasi diantaranya:

- Starting, artinya individu mulai mencari informasi misalnya bertanya pada seseorang yang ahli dalam salah satu bidang keilmuan yang diminati oleh individu tersebut.

- Chaining, yaitu menulis hal-hal yang dianggap penting dalam sebuah catatan kecil

- Browsing, yaitu suatu kegiatan mencari informasi yang terstruktur atau semi struktur.

- Differentiating, yaitu pembagian atau reduksi data atau pemilihan data, mana yang akan digunakan dan mana yang tidak perlu.

- Monitoring, yaitu selalu memantau atau mencari beritaberita atau informasi yang terbaru (up to date).

- Extracting, yaitu mengambil salah satu informasi yang berguna dalam sebuah sumber informasi tertentu, misalnya mengambil salah satu file dalam www dalam dunia internet.

- Verifying, yaitu mengecek ukuran data yang telah diambil.

- Ending, yaitu akhir dari pencarian.

- Presentation, yaitu tahapan dimana ada perasaan lega, perasaan puas ketika pencarian berjalan dengan baik atau kekecewaan jika terjadi sebaliknya.

\section{METODE}

\section{Jenis dan Pendekaan Penelitian}

Dalam penelitian pada kali ini penulis menggunakan jenis penelitian deskriptif, observasi deskriptif dilakukan peneliti pada saat memasuki situasi sosial tertentu sebagai objek penelitian(Sugiono,2017). Dimana penelitian deskriptif ini memberikan gambaran secara jelas mengenai Perilaku Pencarian Informasi Mahasiswa Jurusan Ilmu Perpustakaan Universitas Islam Negeri Syarif Hidayatullah Jakarta Dalam Masa Pandemik Covid 19. Sedangkan pendekatan yang penulis gunakan dalam penelitian ini merupakan pendekatan kualitatif, yaitu metode penelitian yang berlandaskan pada filsafat postpositive/enterpretif, digunakan untuk meneliti pada kondisi objek ilmiah (Sugiono,2017). 


\section{Populasi dan Sampel}

Populasi merupakan kesulurah objek dalam penelitian dimana disini populasi merupakan Mahasiswa Jurusan Ilmu Perpustakaan Universitas Islam Negeri Syarif Hidayatullah Jakarta yang berjumlah 500 orang. Sedangkan sampel adalah jumlah dan karakteristik yang dimiliki oleh populasi tersebut, untuk itu sampel diambil dari populasi harus betul-betul representative penelitian inni melaukan teknik stratified sampling teknik ini mengambil sampel dengan populasi memiliki tingkatan dan setiap tingkatan memiliki karakteristiknya tersendiri.

\section{HASIL DAN PEMBAHASAN}

\section{Hasil Penelitian}

Analisis data penelitian dilakukan dengan data yang terkumpul melalui google form dan dihitung kembali secara manual para mahasiswa dapat bekerjasama dengan cara bersedia mengisi kuesioner yang kami berikan, penyebaran kuesioner dilakukan pada tanggal 18-22 Juni 2010. Karena terkendala situasi kami menyebarkan kuesioner via daring menggunakan media social wa dari sampel yang kami tentukan sejumah 83 hanya 31 orang saja yang mengisi kuesioner ini.

Perilaku Pencarian Informasi; Perilaku pencaian informasi menurut Wilson terdapat 8 tahapan diantaranya:

\section{Starting (memulai)}

a. Perilaku pencarian informasi mahasiswadisaat memulai mencari informasi

Hasil penelitian menunjukkan bahwa hampir seluruhnya menentukan topic pencarian mereka telebih dahulu sebelum melakukan pencarian informasi (25 responden / 80,6\%) sedangkan yang langsung mencari ke berbagai sumber berjumlah (3 responden / 9,6\%) begitu pula dengan yang mencatat hal yang diperlukan terlebih dahulu sebelum melakukan pencarian infomasi (3 responden / 9,6\%). Dengan demikian dapat dikatakan bahwa Mahasiswa Jurusan Ilmu Perpustakaan Universitas Islam Negeri Syarif Hidayatullah Jakarta pertama kali menemukan sebuah informasi ialah menentukan topik informasi sebelum mencari informasi.

b. Akses yang lebih diminati mahasiswa ditengah pandemik covid 19

Berdasarkan hasil dari kuesioner yang disebar $100 \%$ jawaban dari pertanyaan apa akses yang paling disukai saat melakukan pencarian indormasi para responden menjawab akses online dibandingkan dengan akses offline karena adanya beberapa faktor. 
Tabel 2. Akses yang lebih diminati mahasiswa ditengah pandemik covid 19

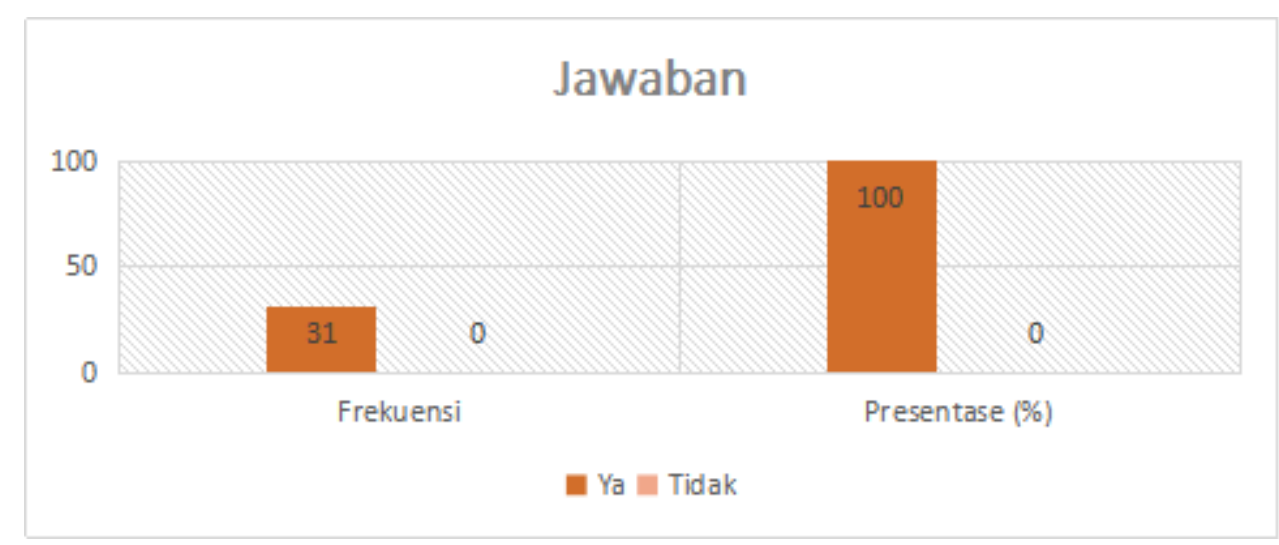

c. Kesulitan yang dihadapi disaat PSBB untuk mencari informasi

Dengan banyaknya responden yang menjawab menggunakan akses online dan terdapat beberapa responden yang merasa masa PSBB ini sulit untuk mendapat atau mencari informasi dikarenakan harus mencari online dan (22 responden / 70,9\%) menjawab ini tidak menyulitkan da nada (9 responden / $29,1 \%$ ) merasa keberatan dan setuju dengan pertanyaan yang kami ajukan yang dapat dilihat pada tabel berikut ini

Tabel 3. Kesulitan yang dihadapi disaat PSBB untuk mencari informasi

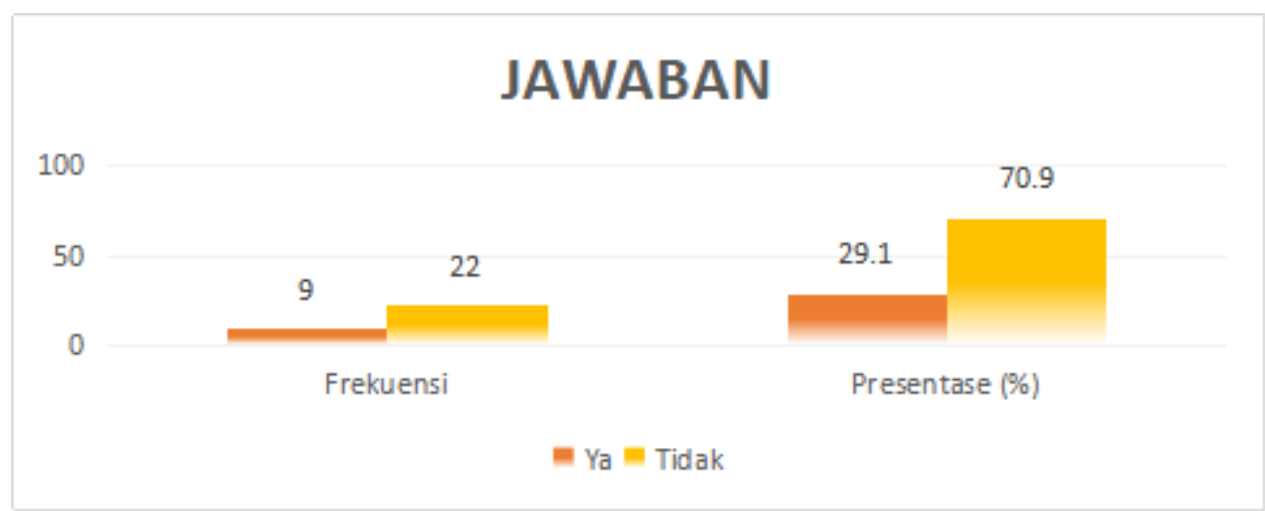

d. Faktor yang membuat sulitnya melakukan pencarian informasi secara online

Pernyataan ini ditujukan untuk responden yang menjawab "iya" pada pertanyaan sebelumnya untuk mengetahui kesulitan apa yang dihadapi disaat pencari informasi ditengah masa PSBB diantaranya (5 responden / 55,5\%) mengatakan bahwa kendala yang mereka hadapi merupakan terbatasnya kuota internet sedangkan (4 responden / 44,4\%) mengatakan kurangnya pengetahuan tentang situs penyedia informasi terpercaya di internet. 


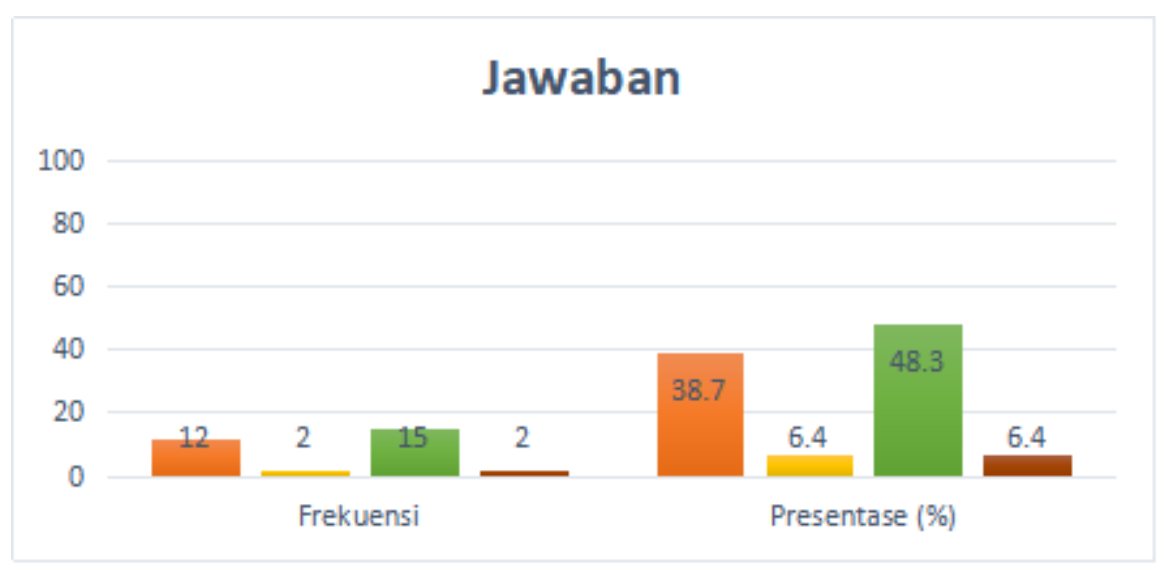

Tabel 4. Faktor yang membuat sulitnya melakukan pencarian informasi secara online

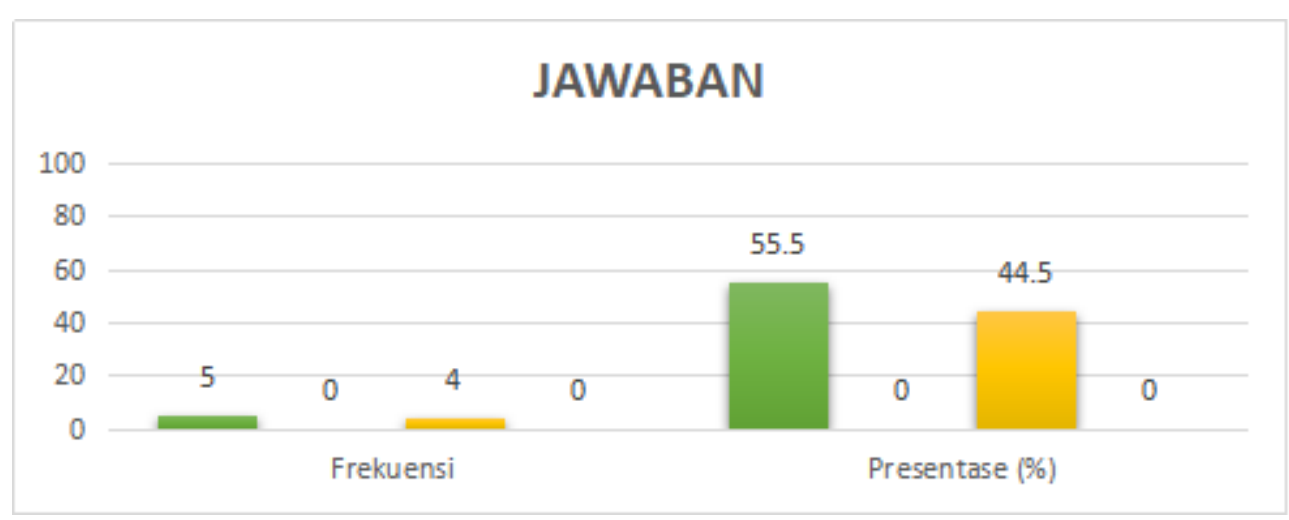

\section{Chaining (menemukan)}

Perilaku Mahasiswa dalam menemukan informasi

Hasil penelitian menunjukkan bahwa sebagian (19 responden / 61,3\%) mencari kata kunci secara langsung dari artikel, skripsi, dll atau daftar rujukan dosen menggunakan laman pencarian google search dan (12 responden / 38,7\%) Mengikuti daftar pustaka dari artikel, skripsi, dll atau daftar rujukan dosen menggunakan laman pencarian google search. Data selengkapnya dapat dilihat pada tabel berikut:

Tabel 5. Perilaku Mahasiswa dalam menemukan informasi

\section{Jawaban}

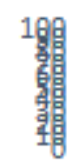

49

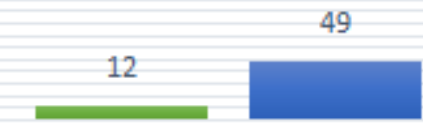

Frekuensi

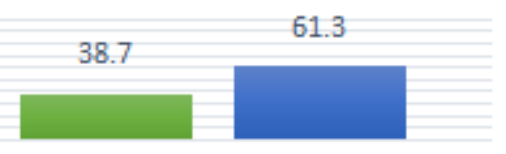

Presentase (\%)

Mengikuti daftar pustaka dari artikel, skripsi, dll atau daftar rujukan dosen menggunakan laman pencarian google search

Mencari kata kunci secara langsung menggunakan laman pencarian google search 
Dengan demikian dapat dikatakan bahwa perilaku pencarian informasi yang paling banyak ditemukan olehMahasiswa Jurusan Ilmu Perpustakaan Universitas Islam Negeri Syarif Hidayatullah Jakarta dalam mengerjakan tugas yang diberikan oleh dosen ialah Mencari kata kunci secara langsung menggunakan laman pencarian google search

\section{Browsing (menelusur)}

a. Perilaku Mahasiswa ketika menelusur menggunakan google search

Berdasarkan hasil penelitian mayoritas jawaban dipilih oleh responden (15 responden / 48,3\%) yaitu Pencarian dengan membatasi jenis file (pdf, doc, xls, ppt), selanjutnya sebanyak (12 orang / 38,7\%) pencarian secara langsung dan selanjutnya (2 responden / 6,4\%) melakukan penulusuran dengan Boolean Logic ( AND, OR, NOT ) dan yang terakhir melakukan penulusuran dengan keyword tanda petik ( “......"), sebanyak ( 2 responden / 6,4\%) yang akan dijabarkan pada tabel berikut

Dengan demikian dapat dikatakan bahwa perilaku pencarian informasi Mahasiswa Jurusan Ilmu Perpustakaan Universitas Islam Negeri Syarif Hidayatullah Jakarta dalam menulusur ialah Melakukan penulusuran dengan membatasi penelusuran dengan jenis file type (PDF, Word, HTML).

b. Perilaku Mahasiswa ketika Jenis infromasi yang sering diambil saat melakukan pencarian informasi

Pilihan yang disediakan oleh google dangat beragam mulai dari artikel jurnal online, skripsi dari repository bahkan web (Wikipedia, blog dsb.) berdasarkan hasil penelitian berikut merupakan beberapa jenis informasi yang dipilih diantaranya artikel jurnal online sebanyak (28 responden / 90,4\%) dan sisanya sebanyak (3 responden / 9,6\%) memilih skripsi yang disediakan di repository yang akan dijelaskan pada tabel berikut

Tabel 7. Jenis informasi yang sering diakses 


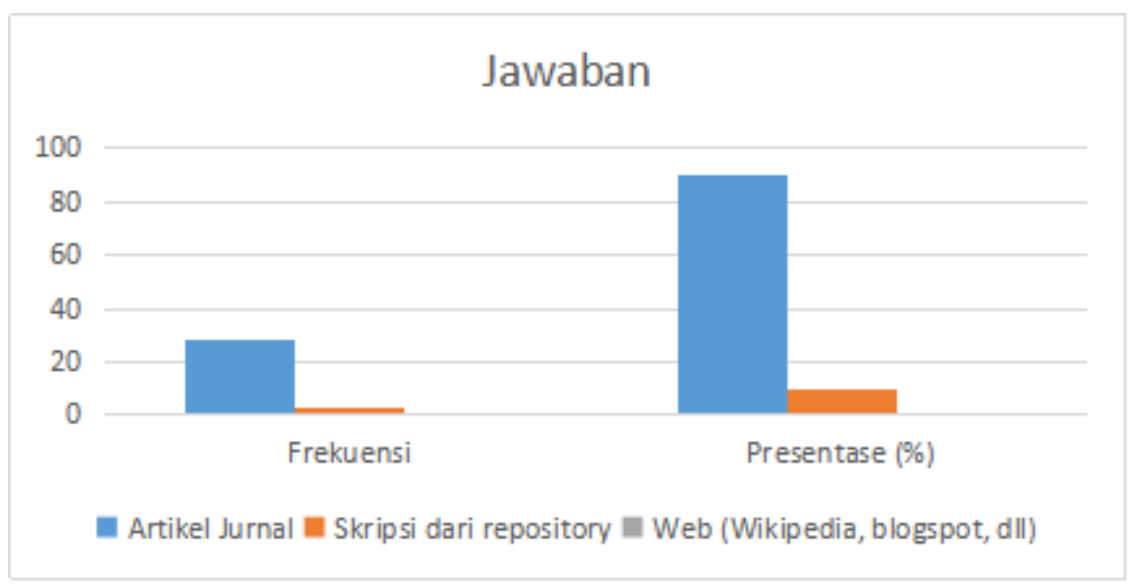

c. Situs favorit mahasiswa saat melakukan pencarian informasi

Berdasarkan penelitian mayoritas dari responden memilih google scholar sebagai situs pencarian favorite untuk melakukan pencarian informasi dengan (15 responden / 48,3\%) selanjutnya dengan presentase (7 responden / 22,5\%) responden memlih jawaban lain yang berarti mereka memliki situs tersendiri untuk melakukan pencarian informasi sedangkan pada urutan selanjurnya dengan (5 responden / 16,1\%) yaitu reasearchgate.net dan pada pilihan terakhir yaitu doaj.org. yang lebih jelasnya dapat dilihat pada tabel berikut:

Tabel 8. Situs favorit ketika melakukan pencarian informasi

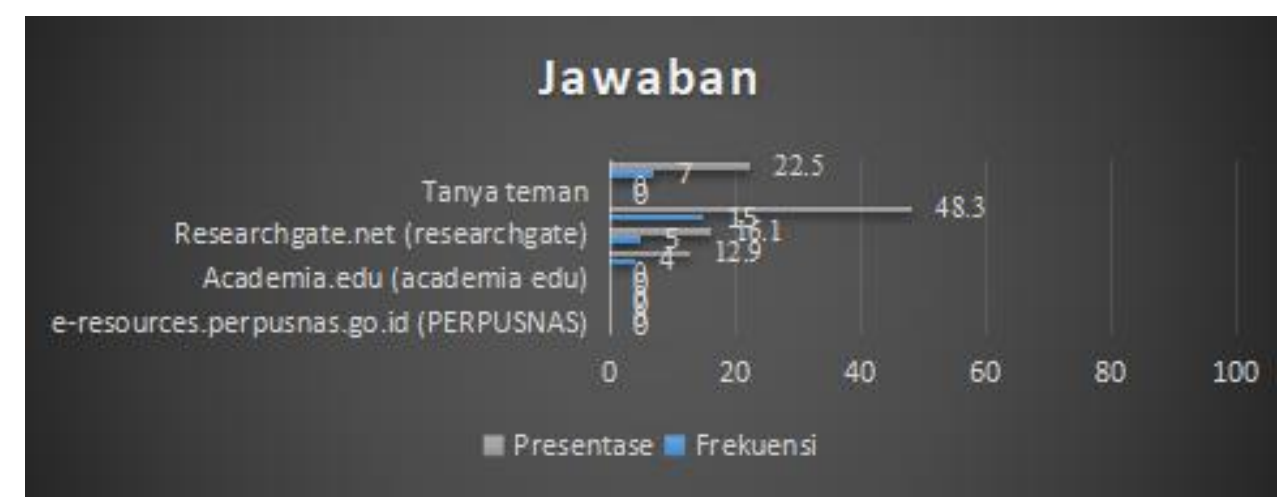

\section{Differentiating (membedakan)}

a. Perilaku Mahasiswa Ketika selesai dalam penelusuran memilah-milah informasi yang dibutuhkan

Perilaku pencarian informasi Mahasiswa Jurusan Ilmu Perpustakaan Universitas Islam Negeri Syarif Hidayatullah Jakarta dalam menelusur memilahmilah informasi yang dibutuhkan terdiri dari Ya dan Tidak Hasil penelitian menunjukkan bahwa hampir seluruhnya ( 31 orang / 100\% ) respondenmenjawab Ya, danterakhir mahasiswa menjawab Tidak satupun 0. Data selengkapnya dapat dilihat pada ttabel berikut ini:

Tabel 9. Perilaku mahasiswa ketika selesai melakukuan penelusuran 


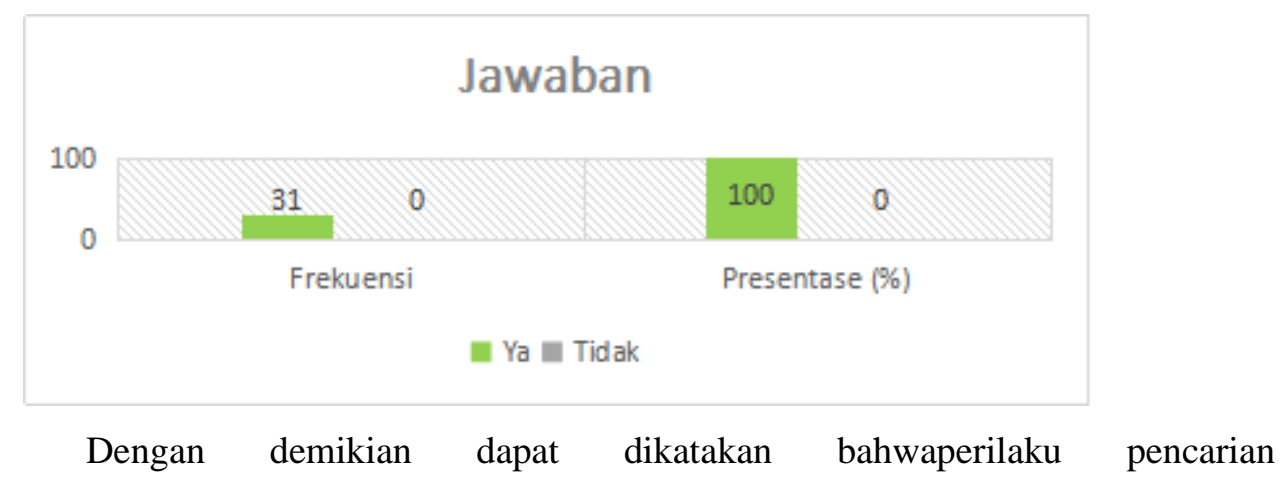
informasi Mahasiswa Jurusan Ilmu Perpustakaan Universitas Islam Negeri Syarif Hidayatullah Jakarta dalam penelusuran memilah-milah informasi yang dibutuhkan.

b. Perilaku pencarian Mahasiswa alasan memilah-milah informasi dari internet.

Berdasarkan data yang terkumpul terdapat beberapa jawaban yang dipilih oleh responden diantaranya pilihan pertama dengan (2 responden / 6,4\%) yaitu Membedakan jenis sumber informasi (web, artikel jurnal, skripsi, dll) sedangkan jawaban kedua dengan (10 responden / 32,2\%) yaitu Membandingkan kualitas informasi antara satu dan yang lain dan yang terakhir dengan (19 responden / 61,2\% yaitu Mengidentifikasi informasi terutama menekankan pada subjek yang dibutuhkan, yang selengkapnya akan dijelaskan pada tabel berikut

Tabel 10. Alasan mahasiswa memilah-milah informasi dari internet



Dengan demikian dapat dikatakan bahwa perilaku pencarian informasi Mahasiswa Jurusan Ilmu Perpustakaan Universitas Islam Negeri Syarif Hidayatullah Jakarta dalam cara memilah-milah informasi dari internet ialah Mengecek sebuah informasi yaitu untuk menemukan subjek yang sesuai dengan apa yang mereka cari.

c. Kecukupan informasi yang didaptkan Mahasiswa ketika mencari informasi menggunakan akses online. 
Berdasarkan hasil penelitian yang kami lakukan terkait kecukupan infromasi yang didapatkan disaat menggunakan akses online dan (16 responden / 51,6\%) menjawab Ya dan (15 responden / 48,4\%) menjawab tidak.

Tabel 11. Kecukupan informasi yang didapatkan Mahasiswa

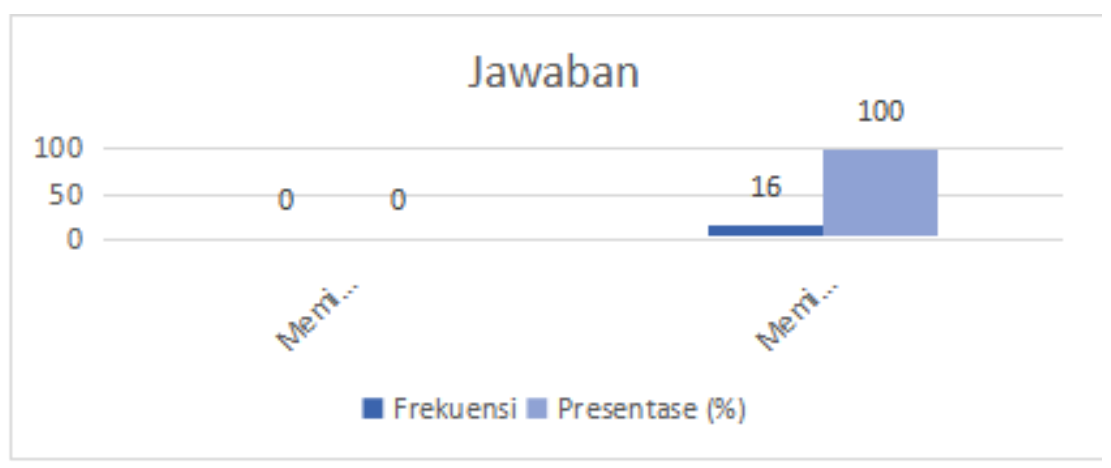

Dengan hasil yang didapatkaan dengan perbedaan yang sangat tipis diantara keduanya hanya selisih 1 responden saja yang berarti banyak mahasiswa yang merasa cukup dengan apa yang mereka dapatkan saat menggunakan akses online d. Apa yang dilakukan Mahasiswa ketika apa yang didapatkan dari internet tidak memenuhi kebutuhannya saat mencari informasi

Menggunakan internet memang tidak selalu memuaskan maka dari itu kami mencari tau apa yang mahasiswa lakukan disaat kebutuhannya tidak terpenuhi dan berdasarkan hasil penelitian (16 responden / 100\% ) memilih mencari informasi kepada sesame teman atau kaka tingkat dan untuk hasil lengkapnya akan dijelaskan pada tabel berikut

Tabel 12. kegiatan ketika tidak menemukan informasi di internet




Berdasarkan tabel diatas bisa dilihat bahwa mahasiswa lebih nyaman untuk meminta informasi kepada teman atau kaka tingkat disaat mereka tidak mendapatkan apa yang mereka cari di internet.

Monitoring (memperhatikan)

a. Perilaku pencarian Mahasiswa ketika memperhatikan perkembangan informasi

Perilaku pencarian informasi Mahasiswa Jurusan Ilmu Perpustakaan Universitas Islam Negeri Syarif Hidayatullah Jakarta dalammemperhatikan perkembangan informasi yang berhubungan dengankebutuhan informasi terdiri dari Ya dan TidakHasil penelitian menunjukkan bahwa hampir seluruhnya ( 28responden / 90,3 \% ) responden menjawab Ya dan ( 3 responden / 19,7\%)responden menjawab Tidak. Untuk lebih jelasnya, Data selengkapnya dapat dilihat pada tabel berikut ini:

Tabel 12. Perilaku pencarian Mahasiswa ketika memperhatikan perkembangan informasi

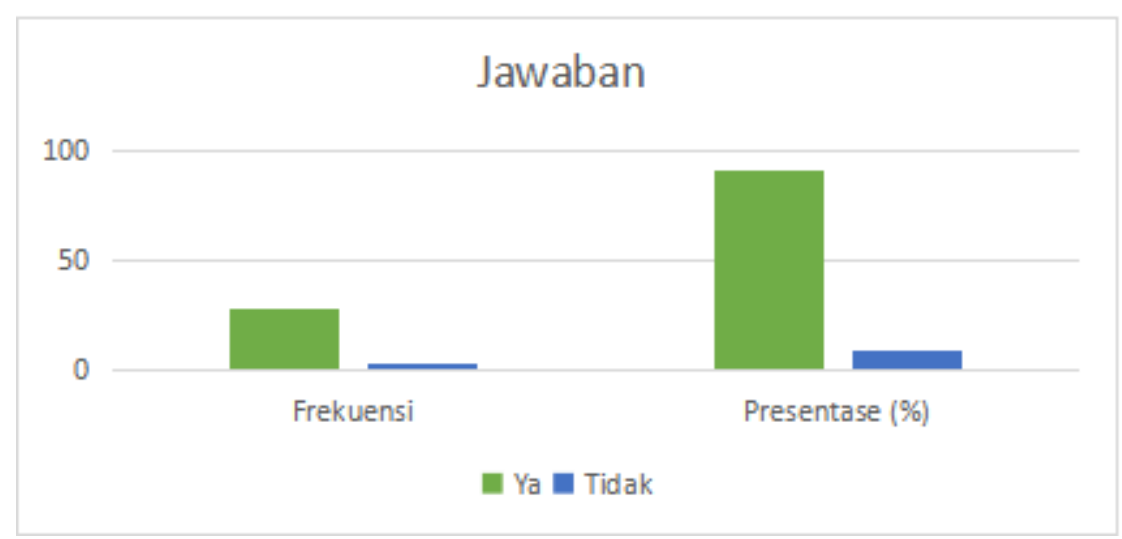

Dengan demikian dapat dikatakan bahwa perilaku pencarian informasi Mahasiswa Jurusan Ilmu Perpustakaan Universitas Islam Negeri Syarif Hidayatullah Jakarta sangat memperhatikan perkembangan informasi.

b. Perilaku pencarian informasi Mahasiswa disaat melakukan pencarian informasi lagi

Banyak sekali alasan mahasiswa untuk mencari kembali informasinya dan berdasarkan hasil penelitian ada beberapa alasan yang dipilih oleh responden diantara dengan hasil (13 responden / 46,4\%) yaitu tidak pernah puas dan selanjutnya dengan Informasi yang dikumpulkan berakhir dengan tidak terpakai dengan (4 responden / 14,4\%) dan yang terakhir yaitu memiliki jawaban lain dengan (11 responden / 39,2\%) dan akan dijelaskan

Tabel 13. Perilaku pencarian Mahasiswa ketika mencari informasi lagi 


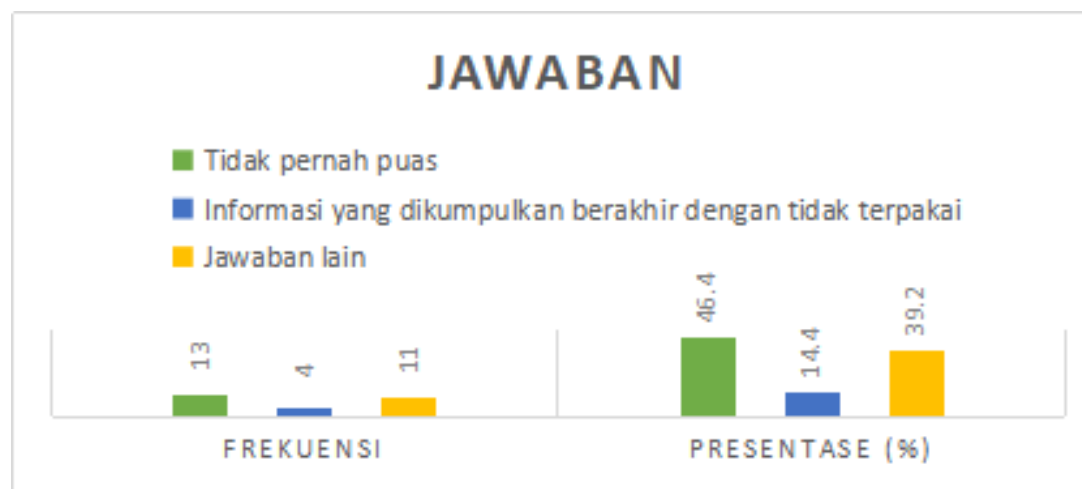

Dengan demikian dapat dikatakan bahwa perilaku pencarian informasi Mahasiswa Jurusan Ilmu Perpustakaan Universitas Islam Negeri Syarif Hidayatullah Jakarta dalam mencari informasi kembali yaitu karena tidak pernah puas

c. Extracting (mengidentifikasi)ketika mengambil poin-poin penting dari informasi.

Berdasrkan apa yang didapatkan dari hasil penelitian mendapatkan jawaban diantaranya (16 responden / 51,6\%) mengunduh informasi tersebut, yang kedua dengan (3 responden / 9,6\%) mengcopy paste dan yang terakhir mencatat informasi dengan (12 responden / 38,7\%) yang akan dijelaskan pada tabel beikut

Tabel 14. Perilaku pencarian Mahasiswa ketika ketika mengambil poin informasi



Dengan demikian dapat dikatakan bahwa perilaku pencarian informasi Mahasiswa Jurusan Ilmu Perpustakaan Universitas Islam Negeri Syarif Hidayatullah Jakarta ketika mengambil poin-poin penting dari informasi ialah mengunduh informasi tersebut.

Verifying (memeriksa)

a. Perilaku pencarian Mahasiswa ketika melakukan pemeriksaan atau pengecekan terhadap informasi yang diperoleh

Hasil penelitian menunjukkan bahwa hampir seluruhnya (29 responden / $93,5 \%$ ) responden menjawab Ya, dan sebgain kecil ( 2 orang / 6,5\%) responden menjawab Tidak 
Tabel 15. Perilaku pencarian Mahasiswa ketika ketika pengecekan terhadap informasi

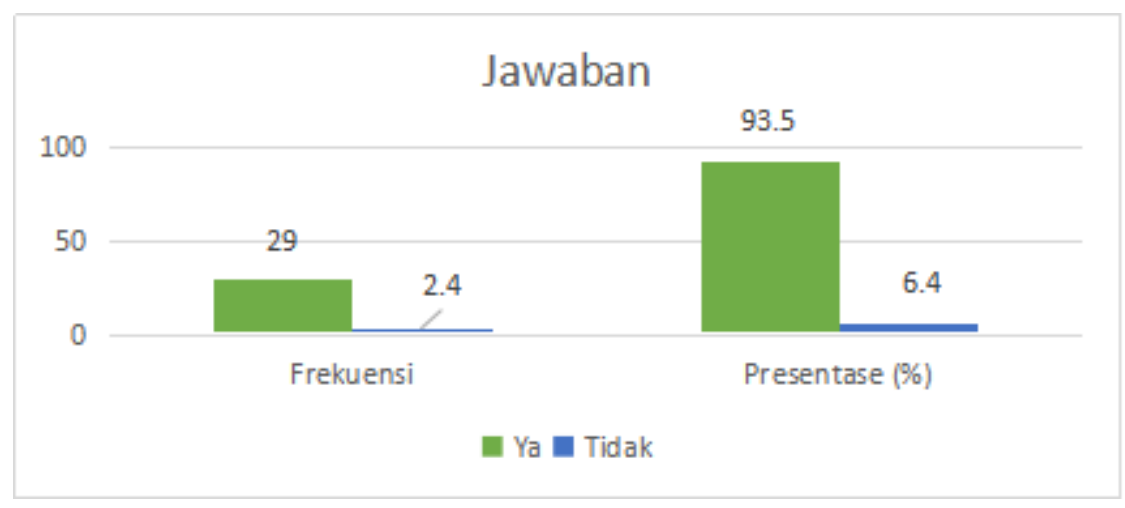

Dengan demikian dapat dikatakan bahwa mahasiswa Jurusan Ilmu Perpustakaan Universitas Islam Negeri Syarif Hidayatulla Jakarta melakuka pemeriksaan atau pengecekan terhadap informasi yang diperoleh.

b. Cara pencarian Mahasiswa ketika memeriksa atau mengecek informasi

Hasil penelitian menunjukkan bahwa (18 responden / 62,6\%) Mencari informasi dari sumber lain di internet dan membandingkannya, selanjutnya (11 responden / 37,4\%) Mencocokkan informasi dengan informasi yang sudah ditemukan terlebih dahulu dan akan dijelaskan pada tabel berikut

Tabel 16. Cara pencarian Mahasiswa ketika memeriksa atau mengecek informasi

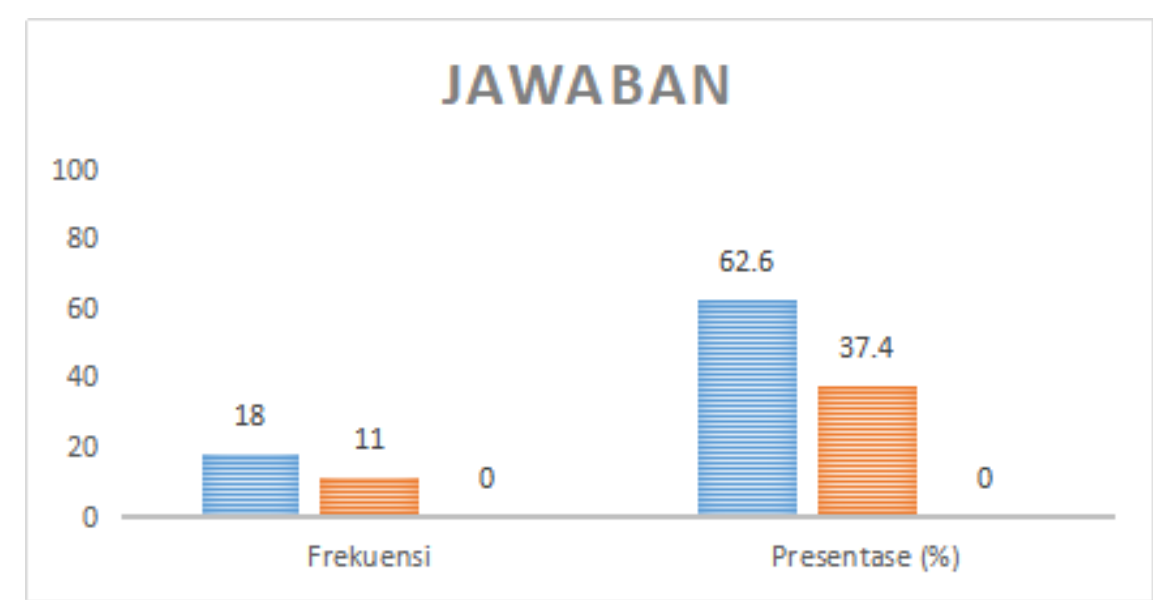

Dengan demikian dapat dikatakan bahwa perilaku pencarian Mahasiswa Jurusan Ilmu Perpustakaan Universitas Islam Negeri Syarif Hidayatullah Jakarta cara mengecek sebuah informasi ialah Membandingkannya dengan sumber lain di internet.

Ending (Selesai)

a. Perilaku pencarian Mahasiswa setelah selesai dalam mencari informasi

Hasil penelitian menunjukkan bahwa (8 responden / 25,4\%) langsung memanfaatkannya, ( 8 responden / 25,4\%) dan sisanya (15 responden / 48,2\%) 
membuat kesimpulan terlebih dahulu dari seluruh informasi dan untuk lebih jelasnya akan dijelaskan pada tabel berikut:

Tabel 17. Perilaku pencarian Mahasiswa setelah selesai dalam mencari informasi

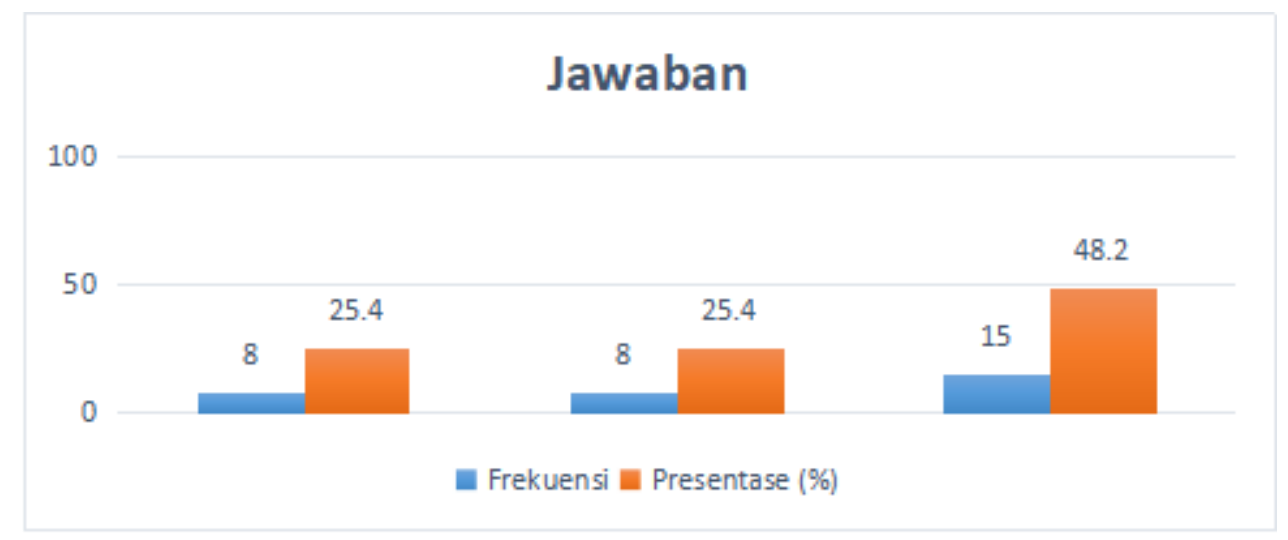

Dengan demikian dapat dikatakan bahwa perilaku pencarian informasi Mahasiswa Jurusan Ilmu Perpustakaan Universitas Islam Negeri Syarif Hidayatullah Jakarta setelah selesai dalam mencari informasi ialah membuat kesimpulan terlebih dahulu dari seluruh informasi

\section{Pembahasan}

\section{Perilaku Pencarian Informasi}

\section{Starting (Memulai)}

a. Perilaku pencarian informasi mahasiswa jurusan ilmu perpustakaan disaat memulai mencari informasi

Dari hasil penelitian bisa dilihat bahwa 25 responden dengan presentase $80,8 \%$ memilih untuk menentukan topic terlebih dahulu sebelum melakukan pencarian informasi. Dengan demikian dapat dikatakan bahwa Mahasiswa Jurusan Ilmu Perpustakaan Universitas Islam Negeri Syarif Hidayatullah Jakarta pertama kali menemukan sebuah informasi ialah Menentukan topik informasi sebelum mencari informasi.

b. Akses yang lebih diminati mahasiswa jurusan ilmu perpustakaan ditengah pandemik covid 19

Berdasarkan hasil dari kuesioner yang disebar $100 \%$ jawaban dari pertanyaan apa akses yang paling disukai saat melakukan pencarian informasi para responden menjawab akses online

c. Kesulitan yang dihadapi disaat PSBB untuk mencari informasi 
Dengan banyaknya responden yang menjawab menggunakan akses online dan terdapat beberapa responden yang merasa masa PSBB ini sulit untuk mendapat atau mencari informasi dikarenakan harus mencari online dan (22 responden / 70,9\%)

d. Faktor yang membuat sulitnya melakukan pencarian informasi secara online

Berdasarkan hasil penelitian terdapat jawaban bahwa masalah yang mereka hadapi disaat melakukan pencarian secara online ialah terbatasnya kuota internet dengan 5 responden dengan 55,5\%.

\section{Chaining (Menemukan)}

Perilaku Mahasiswaketika mencari informasi

Dari hasil penelitian menunjukkan bahwa sebagian besar menjawab Mencari kata kunci secara langsung menggunakan laman pencarian google search sebanyak 49 responden dengan presentase 61,3\% Dengandemikian dapat dikatakan bahwa perilaku pencarian informasi yang paling banyak ditemukan olehMahasiswa Jurusan Ilmu Perpustakaan Universitas Islam Negeri Syarif Hidayatullah Jakarta dalam mengerjakan tugas yang diberikan oleh dosen ialah Mencari kata kunci secara langsung menggunakan laman pencarian google search

\section{Browsing (Menelusur)}

a. Perilaku Mahasiswa ketika menelusur menggunakan google search

Berdasarkan hasil penelitian membatasi penelusuran jenis file type (PDF, Word, HTML) merupakan pilihan yang banyak dipilih oleh responden dengan 15 responden dengan presentase 48,3\% Dengan demikian dapat dikatakan bahwa perilaku pencarian informasi Mahasiswa Jurusan Ilmu Perpustakaan Universitas Islam Negeri Syarif Hidayatullah Jakarta dalam menulusur ialah Melakukan penulusuran dengan membatasi penelusuran dengan jenis file type (PDF, Word, HTML

b.Perilaku Mahasiswa ketika Jenis infromasi yang sering diambil saat melakukan pencarian informasi

Berdasarkan hasil penelitian artikel jurnal merupakan pilihan yang banyak dipilih denga jumlah 28 responden dengan 90,3\% untuk presentasenya maka dari itu artikel jurnal merupakan jenis informasi yang sering diambil oleh Mahasiswa Jurusan Ilmu Perpustakaan. 
c. Situs favorit mahasiswa saat melakukan pencarian informasi

berdasarkan penelitian mayoritas dari responden memilih google scholar sebagai situs pencarian favorite untuk melakukan pencarian informasi dengan (15 responden / 48,3\%) dengan demikian google scholar merupakan situs yang bisa dikatakan memenuhi kebutuhan informasi dari para responden

\section{Differentiating (Membedakan)}

a. Perilaku Mahasiswa Ketika selesai dalam penelusuran memilah-milah informasi yang dibutuhkan

Pencarian informasi sangat dipengaruhi oleh kebutuhan informasi yang diinginkan oleh pengguna. Dari hasil penelitian menunjukkan bahwa hampir seluruh ( 31 responden / 100\%) responden menyatakan membedakan sebuah informasi yang ditemukannya dengan pengetahuan dasar yang telah dimilikinya, dan pengalaman. Artinya, para pemustaka memilah-milah informasi yang dibutuhkannya.

b. Perilaku pencarian Mahasiswa ketika cara memilahmilah informasi dari internet

Berdasarkan data yang terkumpul terdapat beberapa jawaban yang dipilih oleh responden Membandingkan kualitas informasi antara satu dan yang lain dan yang terakhir dengan (19 responden / 61,2\%) merupakan pilihan yang banyak dipilih Dengan demikian dapat dikatakan bahwa perilaku pencarian informasi Mahasiswa Jurusan Ilmu Perpustakaan Universitas Islam Negeri Syarif Hidayatullah Jakarta dalam cara memilah-milah informasi dari internet ialah Mengecek sebuah informasi yaitu untuk menemukan subjek yang sesuai dengan apa yang mereka cari

c. Kecukupan informasi yang didapatkan Mahasiswa ketika mencari informasi menggunakan akses online.

Dalam aspek ini masih membahas tahap keempat dari kegiatan perilaku pencarian informasi. Dalam tahap ini dari hasil penelitian menunjukkan bahwa terjadi persaingan antara kucup dan tidak cukupnya pencarian informasi dengan menggunakan internet / akses online yaitu ya dengan 16 responden dengan presentase $51,6 \%$

d. ketika apa yang didapatkan dari internet tidak memenuhi kebutuhannya saat mencari informasi

Menggunakan internet memang tidak selalu memuaskan maka dari itu kami mencari tau apa yang mahasiswa lakukan disaat kebutuhannya tidak terpenuhi 
dan berdasarkan hasil penelitian (16 responden / 100\% ) memilih mencari informasi kepada sesame teman atau kaka tingkat

\section{Monitoring (Memperhatikan )}

a. Perilaku pencarian Mahasiswa ketika memperhatikan perkembangan informasi

Dalam aspek ini masih membahas tahap kelima dari kegiatan perilaku pencarian informasi. Dalam tahap inidari hasil penelitian menunjukkan bahwa hampir seluruhnya (28 responden / 90,3\%) responden menyatakan Mahasiswa Jurusan Ilmu Perpustakaan Universitas Islam Negeri Syarif Hidayatullah Jakarta memperhatikanperkembangan informasi

b. Perilaku pencarian informasi Mahasiswa disaat melakukan pencarian informasi lagi

Berdasarkan hasil penelitian mengatakan bahwa alasan mereka melakuka pencarian informasi kembali yaitu karena tidak pernah merasa puas dengan 13 responden dengan prresentase $46,4 \%$ Dengan demikian dapat dikatakan bahwa perilaku pencarian informasi Mahasiswa Jurusan Ilmu Perpustakaan Universitas Islam Negeri Syarif Hidayatullah Jakarta dalam mencari informasi kembali yaitu karena tidak pernah puas.

\section{Extracting (Mengidentifikasi)}

Perilaku pencarian Mahasiswa ketika mengambil poin-poin penting dari informasi.

berdasarkan apa yang didapatkan dari hasil penelitian mendapatkan jawaban diantaranya (16 responden / 51,6\%) mengunduh informasi tersebut Dengan demikian dapat dikatakan bahwa perilaku pencarian informasi Mahasiswa Jurusan Ilmu Perpustakaan Universitas Islam Negeri Syarif Hidayatullah Jakarta ketika mengambil poin-poin penting dari informasi ialah mengunduh informasi tersebut.

\section{Verifying (Memeriksa)}

a. Perilaku pencarian Mahasiswa ketika melakukan pemeriksaan atau pengecekan terhadap informasi yang diperoleh

Dari penelitian menunjukkan bahwa hampir seluruhnya (29 responden / 93,5\%) responden menyatakan mahasiswa melakukan pemeriksaan informasi yang diperolehnya.

Dengan demikian dapat dikatakan bahwa perilaku pencarian informasi Mahasiswa Jurusan Ilmu Perpustakaan Universitas Islam Negeri Syarif Hidayatullah Jakarta dalam melakukan pemeriksaan atau pengecekan terhadap informasi yang diperoleh ialah Mahasiswa Jurusan Ilmu Perpustakaan Universitas Islam Negeri Syarif Hidayatullah Jakarta melakukanya dalam mengecek informasi. 
b. Perilaku pencarian Mahasiswa cara mengecek informasi

Hasil penelitian menunjukkan bahwa (18 responden / 62,6\%) Mencari informasi dari sumber lain di internet dan membandingkannya, Dengan demikian dapat dikatakan bahwa perilaku pencarian Mahasiswa Jurusan Ilmu Perpustakaan Universitas Islam Negeri Syarif Hidayatullah Jakarta cara mengecek sebuah informasi ialah Mencocokan sumber informasi yang diperoleh..

\section{Ending (Selesai )}

Perilaku pencarian Mahasiswa setelah selesai dalam mencari informasi

Dari hasil penelitian menunjukan bahwa 15 responden dengan presentase 48,2\% membuat kesimpulan terlebih dahulu dari seluruh informasi Dengan demikian dapat dikatakan bahwa perilaku pencarian informasi Mahasiswa Jurusan Ilmu Perpustakaan Universitas Islam Negeri Syarif Hidayatullah Jakarta setelah selesai dalam mencari informasi ialah membuat kesimpulan terlebih dahulu dari seluruh informasi

\section{KESIMPULAN}

Pada dasarnya terdapat beberapa perihal mengenai perubahan pencarian informasi seperti akses yang mereka gunakan, situs yang mereka gunakan dan kebiasaan-kebiasaan lainnya. Akan tetapi jika dilihat dari hasil penelitian, selain hal-hal yang berkaitan dengan internet kebiasaan perilaku pencarian informasi mahasiswa Jurusan Ilmu Perpustakaan Universitas Islam Negeri Syarif Hidayatullahh Jakarta masih tetap sama.

Namun bisa dilihat terdapat beberapa kendala yang dihadapi oleh mahasiswa dan hal itu cukup mempersulit dan membatasi mereka dalam melakukan pencarian informasi. Alangkah lebih baik jika perpustakaan juga dapat beradaptasi lebih optimal lagi untuk menunjang kebutuhan pemustakanya agar para pemustaka dapat dengan mudah dan efisien dalam melakukan pencarian infromasi. 


\section{DAFTAR PUSTAKA}

Nicholas, David.(1996). Assesing information needs: tools and techniques. London: Aslib Association for Information Management.

Moores, Paul. (1981). "Information users changing expectation and needs". Aslib proceedings.

Morgan, Steve.(1995) Performance Assessment in Academic Libraries. London: Cassell.

Pamuntjak-Sjahrial, Ny. Rusina,. (2000).Pedoman Penyelenggaraan Perpustakaan. Jakarta: Penerbit Djambatan.

Sugiyono.((2017)) Metode Penelitian Manajemen, Bandung : Alfabeta

Sulistyo Basuki. (2010). Pengantar Ilmu Perpustakaan, Jakarta : Universitas Terbuka

Todd, H. (1984). The information needs of newly retired people. Healt Libraries Review

Widiyastuti, Widiyastuti. "PERBANDINGAN TEORI PERILAKU PENCARIAN

INFORMASI MENURUT ELLIS, WILSON DAN KUHLTHAU." Jurnal Pustaka Budaya, Vol3 No.2, hal. 51-64.diakses dari https://journal.unilak.ac.id/index.php/pb/article/view/583

Yusup, M Pawit. (1991).Mengenal Dunia Perptustakaan dan Informasi. Bandung: Rinekacipta.

Yusup, Pawit M.dan Priyo Subekti.(2010). Teori dan Praktik Penelusuran Informasi (Information Retrieval). Jakarta: Kencana. 